Article

\title{
Synthesis and Antidepressant Activity Profile of Some Novel Benzothiazole Derivatives
}

\author{
Ümide Demir Özkay ${ }^{1, *}$, Ceren Kaya ${ }^{1}$, Ulviye Acar Çevik ${ }^{2}$ and Özgür Devrim Can ${ }^{1}$ \\ 1 Department of Pharmacology, Faculty of Pharmacy, Anadolu University, 26470 Eskişehir, Turkey; \\ cer.kaya@anadolu.edu.tr (C.K.); ozgurdt@anadolu.edu.tr (Ö.D.C.) \\ 2 Department of Pharmaceutical Chemistry, Faculty of Pharmacy, Anadolu University, \\ 26470 Eskişehir, Turkey; uacar@anadolu.edu.tr \\ * Correspondence: udemir@anadolu.edu.tr; Tel.: +90-222-335-0580 (ext. 3750)
}

Received: 9 August 2017; Accepted: 5 September 2017; Published: 7 September 2017

\begin{abstract}
Within the scope of our new antidepressant drug development efforts, in this study, we synthesized eight novel benzothiazole derivatives $3 \mathbf{a}-3 \mathbf{h}$. The chemical structures of the synthesized compounds were elucidated by spectroscopic methods. Test compounds were administered orally at a dose of $40 \mathrm{mg} / \mathrm{kg}$ to mice 24,5 and $1 \mathrm{~h}$ before performing tail suspension, modified forced swimming, and activity cage tests. The obtained results showed that compounds $\mathbf{3 c}, \mathbf{3 d}, \mathbf{3} \mathbf{f}-\mathbf{3 h}$ reduced the immobility time of mice as assessed in the tail suspension test. Moreover, in the modified forced swimming tests, the same compounds significantly decreased the immobility, but increased the swimming frequencies of mice, without any alteration in the climbing frequencies. These results, similar to the results induced by the reference drug fluoxetine $(20 \mathrm{mg} / \mathrm{kg}$, po), indicated the antidepressant-like activities of the compounds $\mathbf{3} \mathbf{c}, \mathbf{3 d}, \mathbf{3} \mathbf{f}-\mathbf{3 h}$. Owing to the fact that test compounds did not induce any significant alteration in the total number of spontaneous locomotor activities, the antidepressant-like effects of these derivatives seemed to be specific. In order to predict ADME parameters of the synthesized compounds $\mathbf{3 a}-\mathbf{3 h}$, some physicochemical parameters were calculated. The ADME prediction study revealed that all synthesized compounds may possess good pharmacokinetic profiles.
\end{abstract}

Keywords: activity cage; antidepressant; benzothiazole; modified forced swimming test; tail suspension test

\section{Introduction}

Depression is a common and serious disability-causing mental disorder with high incidence and recurrence [1,2]. It is estimated by the World Health Organization that in the future it will become the second major cause of disability after cardiovascular diseases [2]. Depression is characterized by several clinical symptoms, including sadness, loss of interest or pleasure, disturbed sleep and appetite, feelings of tiredness, low self-esteem or poor concentration [1]. Currently used antidepressant drugs alleviate the symptoms of major depression, but these treatment approaches have many limitations such as requirement of long times to produce therapeutic responses, low response rates, and various side effects $[3,4]$, therefore, there is a strong demand to develop novel antidepressant agents with greater efficacy and fewer adverse effects.

Benzothiazole belongs to a class of bicyclic heterocyclic compounds, formed with a fused benzene and thiazole moiety containing nitrogen and sulphur in its structure [5]. The benzothiazole core has attracted continuing interest for drug development studies, because it has demonstrated a wide spectrum of pharmacological activities such as anticancer [6-8], antiviral [9], antibacterial [7], antituberculosis [10], antimalarial [11], antifungal [7,12], anthelmintic [13], antileishmanial [14], antiinflammatory [15], antidiabetic [16], antioxidant [17], antiasthmatic [18], and immunomodulatory 
properties [19]. Apart from these activities, the benzothiazole moiety has also attracted attention in central nervous system (CNS)-related drug discovery studies. Several pharmacological activities such as analgesic [20,21], anticonvulsant [22,23], anti-Alzheimer [24,25], anticholinesterase [26,27], MAO inhibitory [28], adenosine receptor antagonist [29], and neuroprotective effects [30,31] of benzothiazole derivatives have been reported. Furthermore, there are approved drugs that contain a benzothiazole core. For example, riluzole is used for the treatment of amyotrophic lateral sclerosis. Besides, another benzothiazole-based drug, pramipexole, has been approved for the treatment of Parkinson's disease [32]. In addition to these CNS-related pharmacological effects, various benzothiazole-based compounds have been shown to possess remarkable binding affinities to serotonin transporters, 5HT1A, and also 5HT2A receptors [33,34], which are important sites of action for antidepressant activity. The antidepressant-like activities of several benzothiazole derivatives have been shown by various animal model such as forced swimming and tail suspension tests (TST) [33,35].

Based on the previous papers reporting the antidepressant-like potential of the benzothiazole scaffold, in this study, we synthesized novel compounds containing this ring system and investigated their potential antidepressant-like effects.

\section{Results and Discussion}

\subsection{Chemistry}

Target molecules $\mathbf{3 a}-\mathbf{3 h}$ were synthesized in three steps as shown in Scheme 1. Initially, 5,6-dimethylbenzo[d]thiazol-2-amine (1) were prepared via reaction of 3,4-dimethylaniline, potassium thiocyanate, and bromine. In the second step, compound $\mathbf{1}$ was acetylated with chloroacetyl chloride to afford 2-chloro- $N$-(5,6-dimethylbenzo[d]thiazol-2-yl) acetamide (2). Finally, compound 2 was reacted with piperazine or piperidine derivatives in acetone to obtain target compounds (3a-3h).

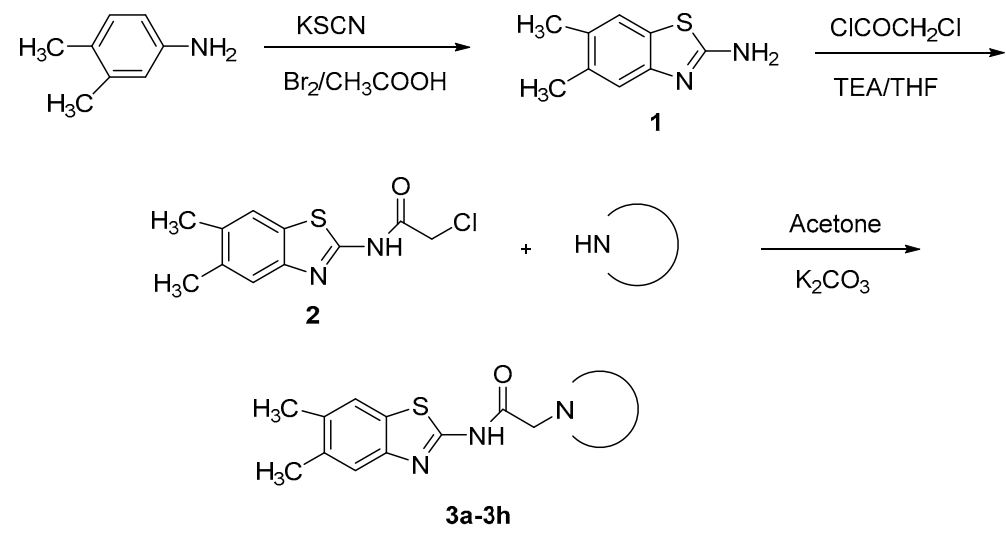

Comp.

Scheme 1. Synthesis of the compounds $3 a-3 h$. 
Structure elucidations of the final compounds were performed by FT-IR, ${ }^{1} \mathrm{H}-\mathrm{NMR},{ }^{13} \mathrm{C}-\mathrm{NMR}$ and HRMS spectroscopic methods. In the IR spectra, significant stretching bands due to N-H, C=O bonds at $3315-3238 \mathrm{~cm}^{-1}$ and 1705-1685 $\mathrm{cm}^{-1}$, respectively, were observed. The stretching absorption belonging to the 1,4-disubstituted benzene unit was determined at $839-831 \mathrm{~cm}^{-1}$. In the ${ }^{1} \mathrm{H}-\mathrm{NMR}$ spectra, N-H and $-\mathrm{CH}_{2}$ protons in the amide group observed as a singlet at 12.01-11.84 ppm and 3.38-3.01 ppm, respectively. The $-\mathrm{CH}_{3}$ protons gave a singlet peak between $2.24-2.32 \mathrm{ppm}$. The $\mathrm{C} 4$ and $\mathrm{C} 7$ protons of the benzothiazole ring gave peaks at 7.70-7.36 and 7.53-7.20 ppm as a singlet, respectively. In the ${ }^{13} \mathrm{C}-\mathrm{NMR}$ spectra carbon of $\mathrm{C}=\mathrm{O}$ group was assigned to the peaks at $169.62-171.27 \mathrm{ppm}$. All measured mass and isotope scores were compatible with calculated values for the compounds $\mathbf{3 a}-\mathbf{3 h}$.

\subsection{Pharmacology}

In this study, based on the antidepressant activity potential of benzothiazole-based compounds, we searched for potential antidepressant-like effects of the newly synthesized benzothiazole derivatives 3a-3h through TST and modified forced swimming tests (MFST). Activity cage tests were also incorporated into the experimental protocol to evaluate any possible effect of the test compounds on the spontaneous locomotor activities of mice. Test compounds were administered to the mice at a dose of $40 \mathrm{mg} / \mathrm{kg}$, which was previously reported for benzothiazole-based compounds [33].

As represented in Figure 1, the immobility time of the mice treated with compounds $\mathbf{3 c}, \mathbf{3 d}, \mathbf{3} \mathbf{f}-\mathbf{3 h}$ were lower than the corresponding values of the control group in TST $[\mathrm{F}(9,50)=12.29 ; p<0.001]$. Fluoxetine, used as a reference drug, also reduced the immobility time of animals, as expected. However, compounds $\mathbf{3 a}, \mathbf{3} \mathbf{b}$ and $\mathbf{3 e}$ were ineffective in TST (Figure 1).

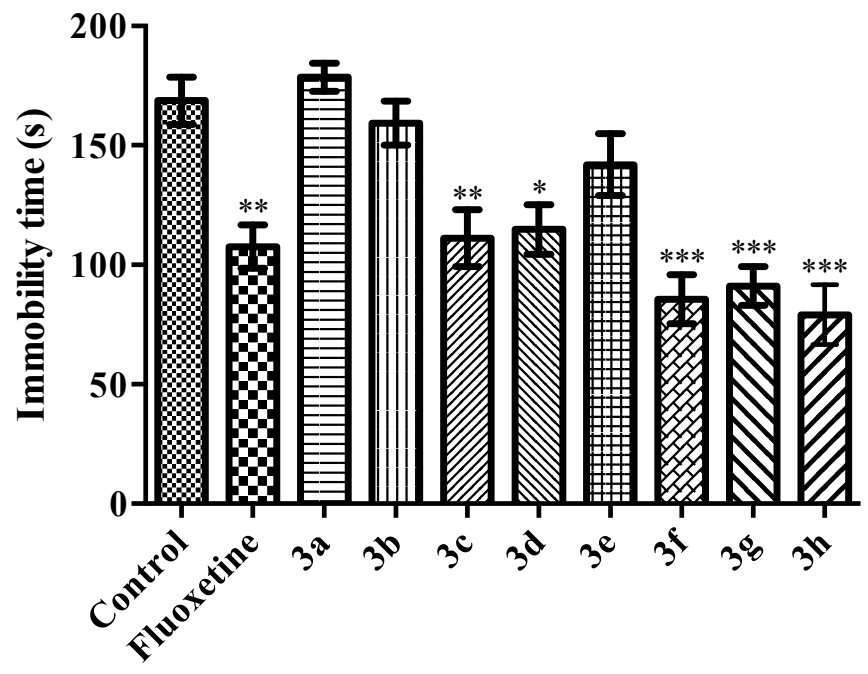

Figure 1. The effects of the test compounds $3 \mathbf{a}-3 \mathbf{h}(40 \mathrm{mg} / \mathrm{kg})$ and fluoxetine $(20 \mathrm{mg} / \mathrm{kg})$ on the immobility time of the mice in TST. Significant differences versus control values, ${ }^{*} p<0.05,{ }^{* *} p<0.01$, *** $p<0.001$. Values are given as mean $\pm \mathrm{SEM},(n=6)$.

As shown in Figure 2, like the reference drug fluoxetine, administration of compounds $\mathbf{3 c}$, 3d, $3 \mathbf{f}-\mathbf{3 h}$ significantly decreased the immobility $[\mathrm{F}(9,50)=14.23 ; p<0.001]$ (Figure 2) but increased the swimming frequencies $[\mathrm{F}(9,50)=12.54 ; p<0.001]$ (Figure 3 ) of mice without affecting the climbing behavior $[\mathrm{F}(9,50)=1.11 ; p>0.05]$ in the MFST (Figure 4 ). However, compounds $\mathbf{3 a}, \mathbf{3 b}$ and $\mathbf{3 e}$ were ineffective in MFST (Figures 2-4). 


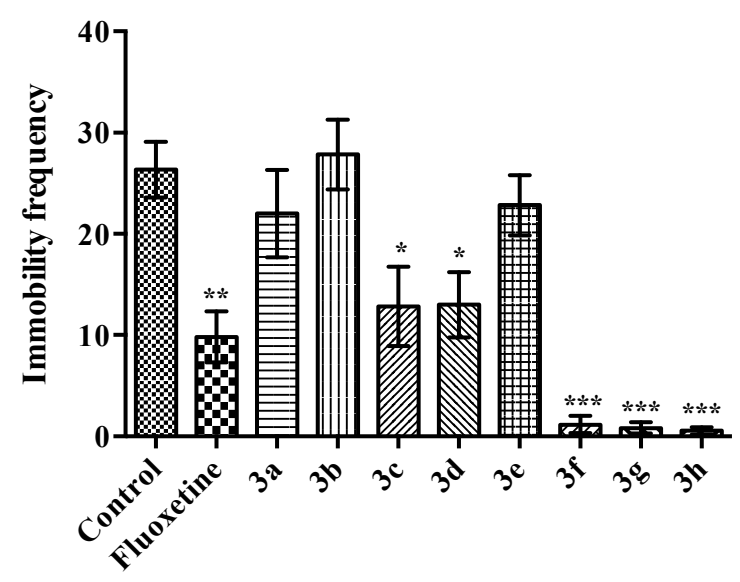

Figure 2. The effects of the test compounds $3 \mathbf{a}-3 \mathbf{h}(40 \mathrm{mg} / \mathrm{kg})$ and fluoxetine $(20 \mathrm{mg} / \mathrm{kg})$ on the immobility frequencies of the mice in MFST. Significant differences versus control values, ${ }^{*} p<0.05$, ** $p<0.01,{ }^{* * *} p<0.001$. Values are given as mean $\pm \mathrm{SEM},(n=6)$.

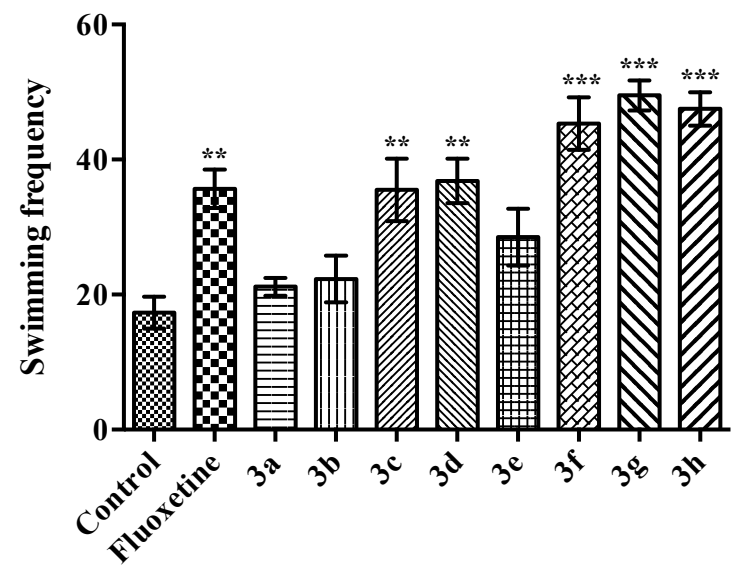

Figure 3. The effects of the test compounds $3 \mathbf{a}-3 \mathbf{h}(40 \mathrm{mg} / \mathrm{kg})$ and fluoxetine $(20 \mathrm{mg} / \mathrm{kg})$ on the swimming frequencies of the mice in MFST. Significant differences versus control values, ${ }^{* *} p<0.01$, *** $p<0.001$. Values are given as mean \pm SEM, $(n=6)$.

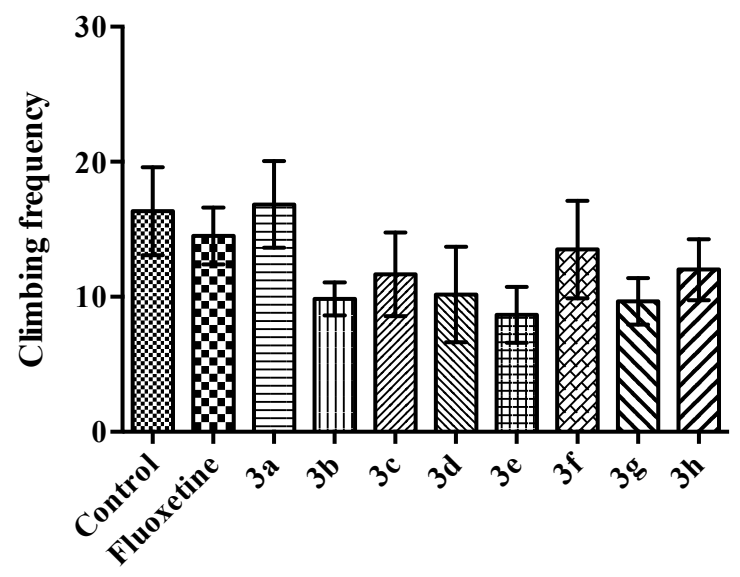

Figure 4. The effects of the test compounds $3 \mathbf{a}-3 \mathrm{~h}(40 \mathrm{mg} / \mathrm{kg})$ and fluoxetine $(20 \mathrm{mg} / \mathrm{kg})$ on the climbing frequencies of the mice in MFST. Values are given as mean $\pm \mathrm{SEM},(n=6)$. 
Total number of horizontal $[\mathrm{F}(8,45)=0.79 ; p>0.05]$ (Figure 5$)$ or vertical $[\mathrm{F}(8,45)=0.85 ; p>0.05]$ (Figure 6) spontaneous locomotor activities of the animals did not alter following the administration of the test compounds.

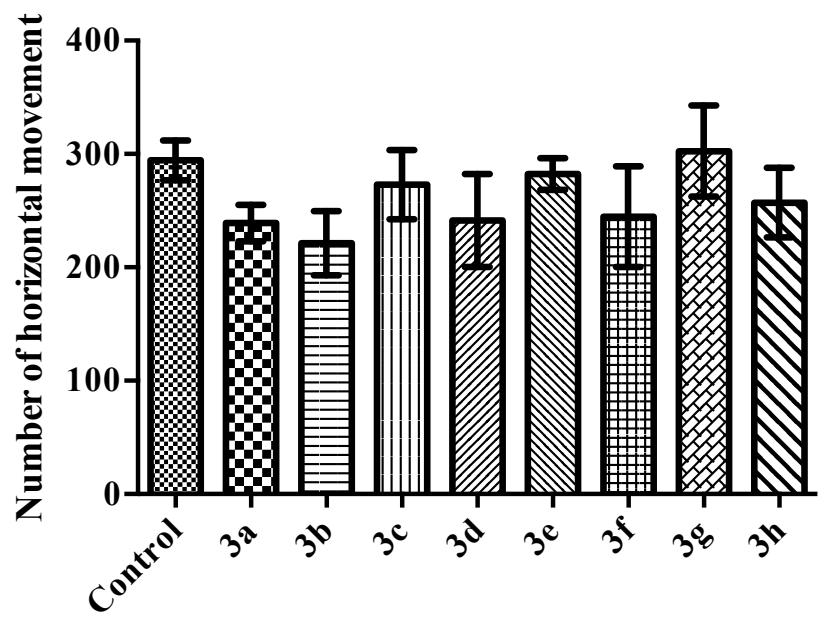

Figure 5. The effects of the test compounds $3 \mathbf{a}-3 \mathbf{h}(40 \mathrm{mg} / \mathrm{kg})$ on the horizontal locomotor activities of the mice in activity cage test. Values are given as mean $\pm \mathrm{SEM},(n=6)$.

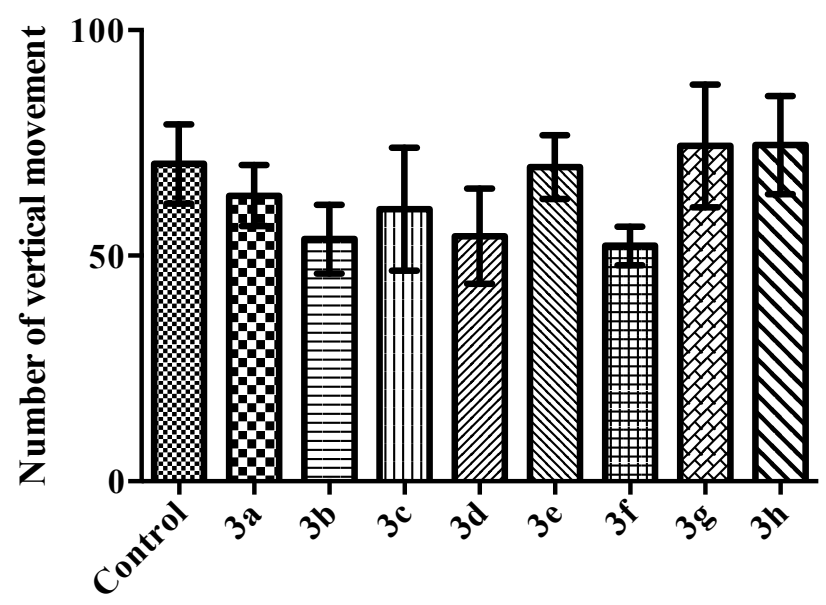

Figure 6. The effects of the test compounds $3 \mathbf{a}-3 \mathbf{h}(40 \mathrm{mg} / \mathrm{kg})$ on the vertical locomotor activities of the mice in activity cage test. Values are given as mean $\pm \mathrm{SEM},(n=6)$.

TST and MFST, rapid and validated animal tests, are widely used for screening the antidepressant-like activity [36]. In both of these tests, animals are exposed to a short-term and inescapable stress. Mice that are hanged from their tails in TST or forced to swim in a restricted space in MFST, initially carry out escape behaviors and then experience an "immobile posture" reflecting the behavioral despair phenomenon. The immobility behavior is accepted to associate with the depressive-like state of the animals and thus, agents reducing duration or frequency of the immobility are supposed to possess antidepressant-like effect [36-39].

In our study, in the TST and MFST, compounds 3c, 3d, 3f-3h induced significant decreases in the duration (Figure 1) and the frequencies (Figure 2) of immobility behaviors of mice, respectively. These findings pointed out the antidepressant-like effects of compounds $\mathbf{3 c}, \mathbf{3 d}, \mathbf{3} \mathbf{f}-\mathbf{3 h}$.

MFST, superior to TST, allows to establish correlations between the "analyzed behaviors" and the "involved neurotransmitter systems". Namely, decrease in the immobility with simultaneous increase in the swimming behavior is related to the enhanced serotonergic neurotransmission. On the 
other hand, agents acting on the noradrenergic system reduce immobility with a corresponding increase in the climbing behavior [36,40,41]. In this study, compounds $\mathbf{3 c}, \mathbf{3 d}, \mathbf{3} \mathbf{f}-\mathbf{3 h}$, similar to serotonergic agent fluoxetine, induces significant decrease in the immobility and increase in the swimming frequencies of mice (Figures 2 and 3). These findings pointed out that serotonergic rather than noradrenergic system plays a significant role in the antidepressant-like effects of compounds $\mathbf{3 c}$, $3 d, 3 f-3 h$.

It is known that agents that alter locomotor activity counts of animals may induce false positive or false negative results in TST and MFST [42,43]. In the present study, in order to clarify whether the antidepressant-like effects of the tested compounds are associated with a possible change in the locomotor activities of mice, we performed activity cage tests. Obtained results revealed that test compounds did not induce any alteration in the total number of horizontal or vertical locomotor activities of the mice (Figures 5 and 6). These data indicate that observed antidepressant-like effects of the test compounds were specific.

Most of new drug candidates fail in clinical trials owing to their toxicological profiles and reduced ADME (absorption, distribution, metabolism, and excretion) properties. The late-stage failures significantly cause to growing cost of new drug development. The capability to identify problematic issues early can intensely reduce the amount of missed time and funds, and rationalize the overall development progression. Therefore, pharmacokinetic properties of new drug candidates are extremely vital and should be assessed as early as possible in the drug development process. In this context, ADME prediction can be used to focus lead optimization to improve the preferred features of a compound [44].

In this study, predictions of ADME parameters of synthesized compounds $\mathbf{3 a}-3 \mathrm{~h}$ were carried out using the QikProp 4.8 software [45]. This software calculates the violations of Lipinski's rule of five [46] and Jorgensen's rule of three [47], which evaluate the ADME properties of new drug candidates, and is essential for the optimization of a biologically active compound. The theoretical calculations about the CNS score; number of rotatable bonds (RB) molecular weight (MW), molecular volume (MV), number of hydrogen donors (DHB), number of hydrogen acceptors (AHB), octanol/water partition coefficient $(\log \mathrm{P})$, aqueous solubility $(\log \mathrm{S})$, apparent Caco-2 cell permeability (PCaco), number of likely primer metabolic reactions (PM), percent of human oral absorption (\%HOA), polar surface area (PSA) are presented in Table 1 along with the violations of rules of three (VRT) and five (VRF). According to Lipinski's rule of five, all compounds $3 \mathbf{a}-3 \mathbf{h}$ abide to the rules causing no violation. Moreover, these compounds meet Jorgensen's rule of three with no more than one violation. Besides, it can be seen that all results of the rules of three and five are within the recommended ranges. CNS scores (1-2) of the compounds (Table 1) indicate that all compounds are able to cross through CNS which is essential for antidepressant drugs. However, the compounds $\mathbf{3 a}$ and $\mathbf{3} \mathbf{b}$, carrying piperidine moiety, were inactive. This finding suggests that piperazine ring system has more contribution to antidepressant activity than piperidine moiety.

Among the piperazine bearing compounds $3 \mathbf{c}-3 \mathbf{h}$, compound $3 \mathbf{e}$ was ineffective. Comparing the structural distance of these compounds, it was thought that extended side chain on the 4th position of the piperazine may cause an activity decrease in compound $3 \mathbf{e}$. On the other hand, due to the preliminary pharmacological activity screening, a single dose $(40 \mathrm{mg} / \mathrm{kg})$ of the compounds was administered to animals and a dose-response relationship was not established. Therefore, investigating potential effect of different doses of compound 3e may be beneficial in further studies.

Antidepressant-like potency of compounds $\mathbf{3 c}, \mathbf{3 d}, \mathbf{3} \mathbf{f}-\mathbf{3 h}$ also different from each other (Figures 1 and 2). Although the difference did not reach the statistical significance, compounds $\mathbf{3 f}, \mathbf{3 g}$ and $3 \mathbf{h}$, carrying phenyl or benzyl substituents on 4 th position of piperazine, seemed to be more active than compounds $3 \mathbf{c}$ and $\mathbf{3 d}$. This may be caused by the better penetrance of compounds $\mathbf{3 f}, \mathbf{3 g}$ and $\mathbf{3 h}$ to the CNS; since these compounds have higher scores of $\log \mathrm{P}$, a predictive indicator of lipophilicity and membrane penetration, than $3 \mathbf{c}$ and $\mathbf{3 d}$. 
Table 1. Some physicochemical parameters of the compounds $\mathbf{3 a}-\mathbf{3 h}$ used in prediction of ADME profiles.

\begin{tabular}{|c|c|c|c|c|c|c|c|c|c|c|c|c|c|c|}
\hline Comp & RB & CNS & MW & MV & DHB & AHB & $\log P$ & $\log S$ & PCaco & PM & $\% \mathrm{HOA}$ & PSA & VRF & VRT \\
\hline $3 a$ & 3 & 1 & 303.42 & 1023 & 1 & 6 & 2.58 & -3.55 & 729.17 & 5 & 93.28 & 49.84 & 0 & 0 \\
\hline $3 b$ & 3 & 1 & 317.45 & 1056 & 1 & 6 & 2.78 & -3.78 & 712.35 & 5 & 94.29 & 49.82 & 0 & 0 \\
\hline $3 c$ & 3 & 2 & 318.44 & 1065 & 1 & 8 & 1.43 & -2.01 & 152.72 & 6 & 74.38 & 57.29 & 0 & 0 \\
\hline $3 d$ & 4 & 2 & 332.46 & 1128 & 1 & 8 & 1.83 & -2.39 & 161.61 & 6 & 77.18 & 58.61 & 0 & 0 \\
\hline $3 e$ & 3 & 1 & 398.50 & 1256 & 1 & 7 & 3.93 & -5.42 & 680.86 & 5 & 100.00 & 56.25 & 0 & 0 \\
\hline $3 f$ & 5 & 2 & 412.52 & 1309 & 1 & 8 & 3.33 & -3.98 & 175.24 & 7 & 86.57 & 55.97 & 0 & 1 \\
\hline $3 g$ & 5 & 2 & 428.98 & 1337 & 1 & 8 & 3.58 & -4.35 & 175.24 & 7 & 88.07 & 55.97 & 0 & 1 \\
\hline $3 \mathrm{~h}$ & 8 & 1 & 465.66 & 1562 & 1 & 10 & 3.26 & -3.51 & 39.60 & 9 & 74.63 & 61.00 & 0 & 1 \\
\hline
\end{tabular}

RB: Number of rotatable bonds (recommended value: 0-15); CNS: Predicted central nervous system activity on a -2 (inactive) to +2 (active) scale; MW: Molecular weight (recommended <500 g/mol); MV: Molecular volume in cubic angstroms using a probe with a $1.4 \AA$ radius (recommended value: $500-2000)$; DHB: Estimated number of hydrogen bonds that would be donated by the solute to water molecules in an aqueous solution (recommended value: 0-6); AHB: Estimated number of hydrogen bonds that would be accepted by the solute from water molecules in an aqueous solution (recommended value: 2-20); logP: Predicted octanol/water partition coefficient (recommended value: -2-6.5); $\operatorname{logS}$ : Predicted aqueous solubility (recommended value: $-6.5-0.5 \mathrm{~mol} \mathrm{dm}^{-3}$ ); PCaco: Predicted apparent Caco-2 cell permeability in $\mathrm{nm} / \mathrm{sec}$. Caco-2 cells are a model for the gut-blood barrier. QikProp predictions are for non-active transport (recommended value: $<25$ poor, $>500$ great); PM: Number of likely primer metabolic reactions (recommended value: 1-8); \%HOA: Predicted human oral absorption on 0 to $100 \%$ scale. The prediction is based on a quantitative multiple linear regression model. This property usually correlates well with Human Oral-Absorption, as both measure the same property (recommended value: $>80 \%$ is high, $<25 \%$ is poor); PSA: Van der Waals surface area of polar nitrogen and oxygen atoms and carbonyl carbon atoms (recommended value: 7-200); VRF: Number of violations of Lipinski's rule of five. The rules are: $7<$ PSA $<200$; $\mathrm{MW}<500, \log \mathrm{P}<5, \mathrm{DHB} \leq 5, \mathrm{AHB} \leq 10$. Compounds that satisfy these rules are considered druglike. (The "five" refers to the limits, which are multiples of 5); VRT: Number of violations of Jorgensen's rule of three. The three rules are: $\log \mathrm{S}>-5.7, \mathrm{PCaco}>22 \mathrm{~nm} / \mathrm{s}, \mathrm{PM}<7$. Compounds with fewer (and preferably no) violations of these rules are more likely to be orally available.

\section{Materials and Methods}

\subsection{Chemistry}

All chemicals were purchased either from Sigma-Aldrich (Sigma-Aldrich Corp., St. Louis, MO, USA) or Merck (Merck KGaA, Darmstadt, Germany) and used without further chemical purification. Melting points of the synthesized compounds were determined by a MP90 digital melting point apparatus (Mettler Toledo, Columbus, $\mathrm{OH}$, USA) and were uncorrected. ${ }^{1} \mathrm{H}$ - and ${ }^{13} \mathrm{C}-\mathrm{NMR}$ spectra were recorded in DMSO- $d_{6}$ by a Bruker digital FT-NMR spectrometer (Bruker Bioscience, Billerica, MA, USA) at 300/75 MHz. The IR spectra were obtained on an IR Prestige-21 spectrophotometer (Shimadzu, Tokyo, Japan). LC-MS-MS studies were performed on a Shimadzu IT-TOF-LC-MS-MS system. The purities of compounds were checked by TLC on silica gel 60 F254 (Merck KGaA).

\subsubsection{Synthesis of 5,6-Dimethylbenzo[d]thiazol-2-amine (1)}

3,4-Dimethylaniline (0.04 mol, $4.84 \mathrm{~g})$ and KSCN (0.048 mol, $4.66 \mathrm{~g})$ in glacial acetic acid (10 mL) were cooled in an ice bath. Bromine $(0.048 \mathrm{~mol}, 2.47 \mathrm{~mL})$ in glacial acetic acid $(10 \mathrm{~mL})$ was added dropwise at $0{ }^{\circ} \mathrm{C}$. The mixture was allowed to stir at room temperature overnight. The iced-water $(50 \mathrm{~mL})$ was added in the mixture and then $\mathrm{pH}$ was adjusted to 11 using sodium hydroxide pellets. The precipitate was filtered, dried and recrystallized from ethanol [27].

\subsubsection{Synthesis of 2-Chloro-N-(5,6-dimethylbenzo[d]thiazol-2-yl) Acetamide (2)}

5,6-Dimethylbenzo[d]thiazol-2-amine (1, $0.032 \mathrm{~mol}, 5.7 \mathrm{~g})$ and triethylamine $(0.038 \mathrm{~mol}, 3.85 \mathrm{~mL})$ in THF ( $50 \mathrm{~mL})$ were allowed to stir on an ice bath. Chloroacetyl chloride $(0.032 \mathrm{~mol}, 3.58 \mathrm{~g})$ in THF $(10 \mathrm{~mL})$ was added drop by drop. After this stage, the content was stirred for $1 \mathrm{~h}$ at room temperature. THF was evaporated and the product was recrystallized from ethanol $[27,48]$. 
3.1.3. General Procedure for the Synthesis of N-(5,6-Dimethylbenzo[d]thiazol-2-yl)-2-(4-substituted piperazin/piperidine-1-yl) Acetamides 3a-3h

2-Chloro- $N$-(5,6-dimethylbenzo[d]thiazol-2-yl) acetamide (2, $0.001 \mathrm{~mol}, 0.25 \mathrm{~g})$, potassium carbonate $(0.001 \mathrm{~mol}, 0.138 \mathrm{~g})$ and appropriate piperazine/piperidine derivative $(0.001 \mathrm{~mol})$ were dissolved in acetone. The solution was refluxed at $40{ }^{\circ} \mathrm{C}$ for $12 \mathrm{~h}$. Acetone was evaporated, residue was washed with water, filtered, dried and recrystallized from ethanol [27].

$\mathrm{N}$-(5,6-Dimethylbenzo[d]thiazol-2-yl)-2-(piperidin-1-yl) acetamide (3a). Yield: 78\%. m.p. $167.2{ }^{\circ} \mathrm{C}$. FTIR $\left(\right.$ ATR, $\left.\mathrm{cm}^{-1}\right): 3273(\mathrm{~N}-\mathrm{H}), 1705(\mathrm{C}=\mathrm{O}) .{ }^{1} \mathrm{H}-\mathrm{NMR} \delta(\mathrm{ppm}): 1.38-1.52\left(7 \mathrm{H}, \mathrm{m}\right.$, piperidine $\left.\mathrm{CH}_{2}\right), 2.24(3 \mathrm{H}, \mathrm{s}$, $\left.\mathrm{CH}_{3}\right), 2.30\left(3 \mathrm{H}, \mathrm{s}, \mathrm{CH}_{3}\right), 2.45-2.51\left(3 \mathrm{H}, \mathrm{m}\right.$, piperidine $\left.\mathrm{CH}_{2}\right), 3.20\left(2 \mathrm{H}, \mathrm{s}, \mathrm{CH}_{2}\right), 7.45(1 \mathrm{H}, \mathrm{s}$, benzothiazole, H7), $7.62\left(1 \mathrm{H}, \mathrm{s}\right.$, benzothiazole, H4), $11.84(1 \mathrm{H}, \mathrm{s}, \mathrm{NH}) .{ }^{13} \mathrm{C}-\mathrm{NMR} \delta$ (ppm): 19.96, 20.19, 24.10, 26.02, $54.38,62.65,120.89,121.75,129.61,131.82,134.54,147.98,159.44,171.20(\mathrm{C}=\mathrm{O})$. HRMS $(m / z):[\mathrm{M}+\mathrm{H}]^{+}$ calcd. for $\mathrm{C}_{16} \mathrm{H}_{21} \mathrm{~N}_{3} \mathrm{OS}$ : 304.1466; found: 304.1478 .

N-(5,6-Dimethylbenzo[d]thiazol-2-yl)-2-(4-methylpiperidin-1-yl) acetamide (3b). Yield: 83\%. m.p. 252.5 ${ }^{\circ} \mathrm{C}$. FTIR (ATR, cm $\left.{ }^{-1}\right): 3275(\mathrm{~N}-\mathrm{H}), 1705(\mathrm{C}=\mathrm{O}) .{ }^{1} \mathrm{H}-\mathrm{NMR} \delta(\mathrm{ppm}): 0.88\left(3 \mathrm{H}, \mathrm{s}, \mathrm{CH}_{3}\right), 1.16-1.32$ ( $3 \mathrm{H}, \mathrm{m}$, piperidine), 1.51-1.55 (2H, s, piperidine), 1.97-2.05 (2H, m, piperidine), $2.24\left(3 \mathrm{H}, \mathrm{s}, \mathrm{CH}_{3}\right)$, $2.30\left(3 \mathrm{H}, \mathrm{s}, \mathrm{CH}_{3}\right), 2.87(2 \mathrm{H}, \mathrm{s}$, piperidine $), 3.01\left(2 \mathrm{H}, \mathrm{s}, \mathrm{CH}_{2}\right), 7.20(1 \mathrm{H}, \mathrm{s}$, benzothiazole, H7), $7.36\left(1 \mathrm{H}, \mathrm{s}\right.$, benzothiazole, H4), $11.87(1 \mathrm{H}, \mathrm{s}, \mathrm{NH}) .{ }^{13} \mathrm{C}-\mathrm{NMR} \delta$ (ppm): 19.98, 20. 22, 21.45, 30.05, 33.17, 53.96, 62.68, 120.89, 121.75, 129.61, 131.82, 134.54, 147.98, 159.44, $171.20(\mathrm{C}=\mathrm{O})$. HRMS $(\mathrm{m} / \mathrm{z}):[\mathrm{M}+\mathrm{H}]^{+}$ calcd. for $\mathrm{C}_{17} \mathrm{H}_{23} \mathrm{~N}_{3} \mathrm{OS}: 318.1625$; found: 318.1635 .

N-(5,6-Dimethylbenzo[d]thiazol-2-yl)-2-(4-methylpiperazin-1-yl) acetamide (3c). Yield: 88\%. m.p. $209.7{ }^{\circ} \mathrm{C}$. FTIR (ATR, cm $\left.{ }^{-1}\right): 3277(\mathrm{~N}-\mathrm{H}), 1688(\mathrm{C}=\mathrm{O}) .{ }^{1} \mathrm{H}-\mathrm{NMR} \delta(\mathrm{ppm}): 2.15\left(3 \mathrm{H}, \mathrm{s}, \mathrm{CH}_{3}\right)$, 2.21-2.33 $\left(10 \mathrm{H}, \mathrm{m}\right.$, piperazine $\left.\mathrm{CH}_{2}, \mathrm{CH}_{3}\right), 2.50\left(4 \mathrm{H}\right.$, br.s., piperazine $\left.\mathrm{CH}_{2}\right), 3.22\left(2 \mathrm{H}, \mathrm{s}, \mathrm{CH}_{2}\right)$, $7.43\left(1 \mathrm{H}, \mathrm{s}\right.$, benzothiazole, H7), $7.60(1 \mathrm{H}$, s, benzothiazole, $\mathrm{H} 4), 11.84(1 \mathrm{H}, \mathrm{s}, \mathrm{NH}) .{ }^{13} \mathrm{C}-\mathrm{NMR} \delta(\mathrm{ppm})$ : $19.95,20.20,46.26,53.07,55.16,61.99,120.80,121.72,129.68,131.62,134.41,148.08,158.85,171.16$ (C=O). HRMS ( $m / z):[\mathrm{M}+\mathrm{H}]^{+}$calcd. for $\mathrm{C}_{16} \mathrm{H}_{22} \mathrm{~N}_{4} \mathrm{OS}$ : 319.1576; found: 319.1587 .

$\mathrm{N}$-(5,6-Dimethylbenzo[d]thiazol-2-yl)-2-(4-ethylpiperazin-1-yl) acetamide (3d). Yield: 85\%. m.p. $146.4{ }^{\circ} \mathrm{C}$. FTIR (ATR, cm $\left.{ }^{-1}\right): 3244(\mathrm{~N}-\mathrm{H}), 1685(\mathrm{C}=\mathrm{O}) .{ }^{1} \mathrm{H}-\mathrm{NMR} \delta(\mathrm{ppm}): 1.54\left(3 \mathrm{H}, \mathrm{s}, \mathrm{CH}_{3}\right), 2.25\left(3 \mathrm{H}, \mathrm{s}, \mathrm{CH}_{3}\right)$, $2.31\left(3 \mathrm{H}, \mathrm{s}, \mathrm{CH}_{3}\right), 2.32\left(2 \mathrm{H}, \mathrm{s}, \mathrm{CH}_{3}\right), 2.39\left(4 \mathrm{H}\right.$, br.s., piperazine $\left.\mathrm{CH}_{2}\right), 2.50\left(4 \mathrm{H}\right.$, br.s., piperazine $\left.\mathrm{CH}_{2}\right)$, $3.30\left(2 \mathrm{H}, \mathrm{s}, \mathrm{CH}_{2}\right), 7.53(1 \mathrm{H}, \mathrm{s}$, benzothiazole, H7), $7.70(1 \mathrm{H}, \mathrm{s}$, benzothiazole, $\mathrm{H} 4), 11.86(1 \mathrm{H}, \mathrm{s}, \mathrm{NH})$. ${ }^{13} \mathrm{C}-\mathrm{NMR} \delta$ (ppm): 12.48, 20.01, 20.17, 52.05, 52.75, 53.12, 60.74, 121.34, 121.92, 129.28, 132.90, 135.24, 147.48, 156.96, $169.62(\mathrm{C}=\mathrm{O})$. HRMS $(m / z)$ : [M + H] $]^{+}$calcd. for $\mathrm{C}_{17} \mathrm{H}_{24} \mathrm{~N}_{4} \mathrm{OS}$ : 333.1730; found: 333.1744.

N-(5,6-Dimethylbenzo[d]thiazol-2-yl)-2-(4-(4-fluorophenyl)piperazin-1-yl)acetamide (3e). Yield: 76\%. m.p. $168.5^{\circ} \mathrm{C}$. FTIR (ATR, $\left.\mathrm{cm}^{-1}\right)$ : $3315(\mathrm{~N}-\mathrm{H}), 1701(\mathrm{C}=\mathrm{O}), 831$ (1,4-disubstituted benzene). ${ }^{1} \mathrm{H}-\mathrm{NMR} \delta$ (ppm): $2.25\left(3 \mathrm{H}, \mathrm{s}, \mathrm{CH}_{3}\right), 2.32\left(3 \mathrm{H}, \mathrm{s}, \mathrm{CH}_{3}\right), 2.69\left(4 \mathrm{H}\right.$, br.s., piperazine $\left.\mathrm{CH}_{2}\right), 3.12(4 \mathrm{H}$, br.s., piperazine $\left.\mathrm{CH}_{2}\right), 3.38\left(2 \mathrm{H}, \mathrm{s}, \mathrm{CH}_{2}\right), 6.92-6.97(2 \mathrm{H}, \mathrm{m}$, fluorobenzene $\mathrm{C}-\mathrm{H}), 7.01-7.07(2 \mathrm{H}, \mathrm{m}$, fluorobenzene $\mathrm{C}-\mathrm{H})$, $7.53\left(1 \mathrm{H}, \mathrm{s}\right.$, benzothiazole, H7), $7.70(1 \mathrm{H}, \mathrm{s}$, benzothiazole, $\mathrm{H} 4), 12.01(1 \mathrm{H}, \mathrm{s}, \mathrm{NH}) .{ }^{13} \mathrm{C}-\mathrm{NMR} \delta(\mathrm{ppm})$ : 20.01, 20.18, 49.46, 52.94, 60.61, $115.34(\mathrm{~d}, J=20.9 \mathrm{~Hz}), 117.66$ (d, $J=7.6 \mathrm{~Hz}), 121.35,121.92,129.29$, 131.18, 132.90, 135.25, 148.37, $156.78(\mathrm{~d}, J=234.75 \mathrm{~Hz}), 169.57,171.21(\mathrm{C}=\mathrm{O}) . \operatorname{HRMS}(\mathrm{m} / \mathrm{z}):[\mathrm{M}+\mathrm{H}]^{+}$ calcd. for $\mathrm{C}_{21} \mathrm{H}_{23} \mathrm{~N}_{4}$ OFS: 399.1635; found: 399.1649 .

N-(5,6-Dimethylbenzo[d]thiazol-2-yl)-2-(4-(4-fluorobenzyl)piperazin-1-yl)acetamide (3f). Yield: 81\%. m.p. $120.6{ }^{\circ} \mathrm{C}$. FTIR (ATR, cm $\left.{ }^{-1}\right)$ : $3238(\mathrm{~N}-\mathrm{H}), 1693(\mathrm{C}=\mathrm{O}), 831$ (1,4-disubstituted benzene). ${ }^{1} \mathrm{H}-\mathrm{NMR} \delta$ (ppm): $2.24\left(3 \mathrm{H}, \mathrm{s}, \mathrm{CH}_{3}\right), 2.29\left(3 \mathrm{H}, \mathrm{s}, \mathrm{CH}_{3}\right), 2.38\left(4 \mathrm{H}\right.$, br.s., piperazine $\left.\mathrm{CH}_{2}\right), 2.50(4 \mathrm{H}$, br.s., piperazine $\left.\mathrm{CH}_{2}\right), 3.23\left(2 \mathrm{H}, \mathrm{s}, \mathrm{CH}_{2}\right), 3.44\left(2 \mathrm{H}, \mathrm{s}, \mathrm{CH}_{2}\right), 7.09-7.15(2 \mathrm{H}, \mathrm{m}$, fluorobenzene $\mathrm{C}-\mathrm{H}), 7.30-7.34(2 \mathrm{H}, \mathrm{m}$, fluorobenzene C-H), $7.42(1 \mathrm{H}, \mathrm{s}$, benzothiazole, $\mathrm{H} 7), 7.59(1 \mathrm{H}, \mathrm{s}$, benzothiazole, $\mathrm{H} 4), 11.84(1 \mathrm{H}, \mathrm{s}, \mathrm{NH})$. ${ }^{13} \mathrm{C}-\mathrm{NMR} \delta(\mathrm{ppm}):$ 19.95, 20.19, 52.97, 53.12, 61.61, 62.01, 115.30 (d, J = 20.9 Hz), 120.77, 121.70, 129.69, 
$131.05(\mathrm{~d}, J=7.9 \mathrm{~Hz}), 131.55,134.36,134.90(\mathrm{~d}, J=2.9 \mathrm{~Hz}), 148.10,160.15,161.68$ (d, J = 240.7 Hz), 171. $27(\mathrm{C}=\mathrm{O})$. HRMS $(\mathrm{m} / z)$ : $[\mathrm{M}+\mathrm{H}]^{+}$calcd. for $\mathrm{C}_{22} \mathrm{H}_{25} \mathrm{~N}_{4} \mathrm{OFS}$ : 413.1799; found: 413.1806 .

$\mathrm{N}$-(5,6-Dimethylbenzo[d]thiazol-2-yl)-2-(4-(4-chlorobenzyl)piperazin-1-yl) acetamide (3g). Yield: 77\%. m.p. $115.2{ }^{\circ} \mathrm{C}$. FTIR (ATR, $\mathrm{cm}^{-1}$ ): $3238(\mathrm{~N}-\mathrm{H}), 1693(\mathrm{C}=\mathrm{O}), 839$ (1,4-disubstituted benzene). ${ }^{1} \mathrm{H}-\mathrm{NMR} \delta(\mathrm{ppm})$ : $2.25\left(3 \mathrm{H}, \mathrm{s}, \mathrm{CH}_{3}\right), 2.31\left(3 \mathrm{H}, \mathrm{s}, \mathrm{CH}_{3}\right), 2.40\left(4 \mathrm{H}\right.$, br.s., piperazine $\left.\mathrm{CH}_{2}\right), 2.50\left(4 \mathrm{H}\right.$, br.s., piperazine $\left.\mathrm{CH}_{2}\right)$, $3.30\left(2 \mathrm{H}, \mathrm{s}, \mathrm{CH}_{2}\right), 3.45\left(2 \mathrm{H}, \mathrm{s}, \mathrm{CH}_{2}\right), 7.31(2 \mathrm{H}, \mathrm{d}, J=8.58 \mathrm{~Hz}, 1,4$-disubstituted benzene), $7.37(2 \mathrm{H}, \mathrm{d}, J=$ $8.58 \mathrm{~Hz}, 1$,4-disubstituted benzene), $7.52(1 \mathrm{H}, \mathrm{s}$, benzothiazole, $\mathrm{H7}), 7.69(1 \mathrm{H}, \mathrm{s}$, benzothiazole, $\mathrm{H} 4)$, 11.85 (1H, s, NH). ${ }^{13} \mathrm{C}-\mathrm{NMR} \delta$ (ppm): 19.99, 20.16, 52.91, 53.02, 60.70, 61.53, 121.32, 121.90, 128.58, 129.29, 131.01, 131.86, 132.84, 135.20, 137.79, 147.50, 157.08, 169.66 (C=O). HRMS ( $m / z):[\mathrm{M}+\mathrm{H}]^{+}$calcd. for $\mathrm{C}_{22} \mathrm{H}_{25} \mathrm{~N}_{4} \mathrm{OSCl}$ : 429.1495; found: 429.1510 .

N-(5,6-Dimethylbenzo[d]thiazol-2-yl)-2-(4-(2-(dimethylamino)ethyl)piperazin-1-yl) acetamide (3h). Yield: 74\%. m.p. $132.1^{\circ} \mathrm{C}$. FTIR (ATR, $\left.\mathrm{cm}^{-1}\right): 3257(\mathrm{~N}-\mathrm{H}), 1693(\mathrm{C}=\mathrm{O}) .{ }^{1} \mathrm{H}-\mathrm{NMR} \delta(\mathrm{ppm}): 2.12\left(6 \mathrm{H}, \mathrm{s}, \mathrm{CH}_{3}\right), 2.24(3 \mathrm{H}$, $\left.\mathrm{s}, \mathrm{CH}_{3}\right), 2.31\left(3 \mathrm{H}, \mathrm{s}, \mathrm{CH}_{3}\right), 2.34\left(2 \mathrm{H}, \mathrm{s}, \mathrm{CH}_{2}\right), 2.35\left(2 \mathrm{H}, \mathrm{s}, \mathrm{CH}_{2}\right), 2.41\left(4 \mathrm{H}\right.$, br.s., piperazine $\left.\mathrm{CH}_{2}\right), 2.50(4 \mathrm{H}$, br.s., piperazine $\left.\mathrm{CH}_{2}\right), 3.28\left(2 \mathrm{H}, \mathrm{s}, \mathrm{CH}_{2}\right), 7.52(1 \mathrm{H}, \mathrm{s}$, benzothiazole, $\mathrm{H} 7), 7.69(1 \mathrm{H}$, s, benzothiazole, $\mathrm{H} 4)$, $11.85(1 \mathrm{H}, \mathrm{s}, \mathrm{NH}) .{ }^{13} \mathrm{C}-\mathrm{NMR} \delta$ (ppm): 19.99, 20.16, 46.01, 53.11, 53.48, 56.36, 57.08, 60.76, 121.34, 121.90, $129.29,132.87,135.22,147.48,157.01,169.63(\mathrm{C}=\mathrm{O})$. HRMS $(\mathrm{m} / z):[\mathrm{M}+\mathrm{H}]^{+}$calcd. for $\mathrm{C}_{19} \mathrm{H}_{29} \mathrm{~N}_{5} \mathrm{OS}$ : 376.2174; found: 376.2166 .

\subsection{Prediction of ADME Parameters}

In order to predict ADME parameters of synthesized compounds (3a-3h), some physicochemical parameters were calculated by using the QikProp 4.8 software (Schrödinger, LLC, New York, NY, USA) [45].

\subsection{Pharmacology}

\subsubsection{Animals}

Experiments were realized with adult BALB/c mice (Source: Anadolu University, Center for Animal Experiments and Research, Eskişehir, Turkey, 30-35 g). All animals were maintained under controlled environmental conditions (temperature $25 \pm 1{ }^{\circ} \mathrm{C}$, relative humidity $65 \%$ and $12 \mathrm{~h}$ light-dark cycle-lights on at 8:00 AM). Animals were acclimatized to laboratory conditions $24 \mathrm{~h}$ before the onset of experiment. The animals were maintained and treated during the experiments in accordance with the instructions of the Local Ethical Committee on Animal Experimentation of Anadolu University, Eskişehir, Turkey, which approved this study. All efforts were made to minimize animal suffering and to reduce the number of animals used in the experiments.

\subsubsection{Drugs and Treatments}

Test compounds were administered to the mice at a dose of $40 \mathrm{mg} / \mathrm{kg}$ [33]. As test compounds were dissolved in sunflower oil, control groups received the same volume of it. In order to validate the experiments, fluoxetine ( $20 \mathrm{mg} / \mathrm{kg}$, Sigma-Aldrich Chemical Company), a classical antidepressant drug, was used as a positive control. Test compounds, fluoxetine and vehicle were administrated to animals in a constant $10 \mathrm{~mL} / \mathrm{kg}$ volume of body weight, through an oral gavage three times 24,5 and $1 \mathrm{~h}$ before the experiments [43].

\subsubsection{Behavioral Experiments}

Tail Suspension Test

The TST was realized according to method described previously [39]. Acoustically and visually isolated mice were individually suspended $30 \mathrm{~cm}$ above the floor by their tail using adhesive tape (placed approximately $1 \mathrm{~cm}$ from the tip of the tail). After initial escape-oriented movements, mice 
hung passively and become completely motionless which is defined as immobile posture. The total duration of immobility (s) was recorded during the last 4 of 6 min test duration [49].

Modified Forced Swimming Test

The MFST was performed as described previously [40,50]. Mice were placed individually in a transparent glass cylinder (12 cm in diameter, $30 \mathrm{~cm}$ height), which was filled with water to a height of $20 \mathrm{~cm}$. The temperature of the water was adjusted to $25 \pm 1{ }^{\circ} \mathrm{C}$. Two swimming sessions were performed: an initial 15-min pretest period and $24 \mathrm{~h}$ afterwards a 5-min test period. During the 5-min test, one of the following behavioral categories over a 5-s interval were scored [40,51]:

1. Immobility: Mouse was in an upright position on the surface with its front paws together and making only those movements required to keep the head above the water.

2. Swimming: Mouse was moving in horizontally throughout the swim chamber and crossing into another quadrant.

3. Climbing: Mouse was making vertical movements with its forepaws along the side of the swim chamber.

The water in the cylinder was changed after the test was performed for each mouse to avoid the influence of alarm substances. After both swimming sessions, the animals were removed from the cylinders, dried with towels, and returned to their home cages.

\section{Activity Cage Test}

The locomotor activities were evaluated individually for each animal with activity cage device (Ugo Basile, No. 7420, Varese, Italy). Parts located on two opposite sides of the device produce infrared (IR) beams. Horizontal and vertical movements of the animals were disrupted the IR light beams to the photocells and these interruptions were recorded automatically for $4 \mathrm{~min}$ by apparatus. The floor of the apparatus was cleaned with ethanol solution between tests $[52,53]$.

\subsubsection{Statistical Analyses}

All analyses were performed using the GraphPad Prism 6.01 (GraphPad Software Inc., San Diego, CA, USA). The data used in statistical analyses were acquired from 6 animals for each group. Statistical analysis of the behavioral tests was performed by analysis of variance (ANOVA), which was followed by Tukey's post hoc comparison test. All experimental results are presented as mean (s) \pm standard error of the mean (S.E.M). Probability values less than $0.05(p<0.05)$ were accepted as significant.

\section{Conclusions}

In this study, the antidepressant-like activities of some novel benzothiazole derivative compounds were examined using some in vivo methods. The obtained results indicated that compounds $\mathbf{3 c}$, $\mathbf{3 d}$, and $\mathbf{3 f}-\mathbf{3 h}$ possess antidepressant-like effects in the TST and MFST, with no accompanying effect on locomotor activities of the animals. Moreover, theoretical prediction of ADME properties of the synthesized compounds indicated that all compounds seem to have good pharmacokinetic profiles. In addition to the potent intrinsic pharmacological activities of the tested benzothiazole derivatives, the good pharmacokinetic profiles of these compounds make them interesting drug candidates. However, detailed studies are required to clarify the pharmacological mechanisms underlying the observed antidepressant-like action. Moreover, comprehensive preclinical, and also clinical studies are needed to validate antidepressant efficacy of these compounds.

Acknowledgments: This study was financially supported by Anadolu University Scientific Projects Fund, Project No: $1705 S 312$.

Author Contributions: Ü.D.Ö. and Ö.D.C. designed the research, conducted the animal experiments; Ü.D.Ö., C.K. and Ö.D.C. performed the statistical evaluation, discussed the pharmacological results. U.A.Ç. performed 
the synthetic work. Ü.D.Ö. mainly wrote the manuscript and was also responsible for the correspondence of the manuscript. All authors discussed, edited and approved the final version.

Conflicts of Interest: The authors declare no conflict of interest.

\section{References}

1. Pytka, K.; Podkowa, K.; Rapacz, A.; Podkowa, A.; Żmudzka, E.; Olczyk, A.; Sapa, J.; Filipek, B. The role of serotonergic, adrenergic and dopaminergic receptors in antidepressant-like effect. Pharmacol. Rep. 2016, 68, 263-274. [CrossRef] [PubMed]

2. Wang, G.L.; He, Z.M.; Zhu, H.Y.; Gao, Y.G.; Zhao, Y.; Yang, H.; Zhang, L.X. Involvement of serotonergic, noradrenergic and dopaminergic systems in the antidepressant-like effect of ginsenoside Rb1, a major active ingredient of Panax ginseng C.A. Meyer. J. Ethnopharmacol. 2017, 204, 118-124. [CrossRef] [PubMed]

3. Chandrasekhar, Y.; Ramya, E.M.; Navya, K.; Phani Kumar, G.; Anilakumar, K.R. Antidepressant like effects of hydrolysable tannins of Terminalia catappa leaf extract via modulation of hippocampal plasticity and regulation of monoamine neurotransmitters subjected to chronic mild stress (CMS). Biomed. Pharmacother. 2017, 86, 414-425. [CrossRef] [PubMed]

4. Zhang, Q.; Guo, F.; Fu, Z.W.; Zhang, B.; Huang, C.G.; Li, Y. Timosaponin derivative YY-23 acts as a non-competitive NMDA receptor antagonist and exerts a rapid antidepressant-like effect in mice. Acta Pharmacol. Sin. 2016, 37, 166-176. [CrossRef] [PubMed]

5. Hroch, L.; Aitken, L.; Benek, O.; Dolezal, M.; Kuca, K.; Gunn-Moore, F.; Musilek, K. Benzothiazoles-scaffold of interest for CNS targeted drugs. Curr. Med. Chem. 2015, 22, 730-747. [CrossRef] [PubMed]

6. Yurttaş, L.; Özkay, Y.; Akalın-Çiftçi, G.; Ulusoylar-Yıldırım, Ş. Synthesis and anticancer activity evaluation of $\mathrm{N}$-[4-(2-methylthiazol-4-yl)phenyl]acetamide derivatives containing (benz)azole moiety. J. Enzym. Inhib. Med. Chem. 2014, 29, 175-184. [CrossRef] [PubMed]

7. Lad, N.P.; Manohar, Y.; Mascarenhas, M.; Pandit, Y.B.; Kulkarni, M.R.; Sharma, R.; Salkar, K.; Suthar, A.; Pandit, S.S. Methylsulfonyl benzothiazoles (MSBT) derivatives: Search for new potential antimicrobial and anticancer agents. Bioorg. Med. Chem. Lett. 2017, 27, 1319-1324. [CrossRef] [PubMed]

8. Turan-Zitouni, G.; Özkay, Y.; Özdemir, A.; Kaplancıklı, Z.A.; Altıntop, M.D. Synthesis of some benzothiazole based piperazine-dithiocarbamate derivatives and evaluation of their anticancer activities. Lett. Drug Des. Discov. 2011, 8, 830-837. [CrossRef]

9. Akhtar, T.; Hameed, S.; Al-Masoudi, N.A.; Loddo, R.; La Colla, P. In vitro antitumor and antiviral activities of new benzothiazole and 1,3,4-oxadiazole-2-thione derivatives. Acta Pharm. 2008, 58, 135-149. [CrossRef] [PubMed]

10. Netalkar, P.P.; Netalkar, S.P.; Budagumpi, S.; Revankar, V.K. Synthesis, crystal structures and characterization of late first row transition metal complexes derived from benzothiazole core: Anti-tuberculosis activity and special emphasis on DNA binding and cleavage property. Eur. J. Med. Chem. 2014, 79, 47-56. [CrossRef] [PubMed]

11. Sarkar, S.; Siddiqui, A.A.; Saha, S.J.; De, R.; Mazumder, S.; Banerjee, C.; Iqbal, M.S.; Nag, S.; Adhikari, S.; Bandyopadhyay, U. Antimalarial activity of small-molecule benzothiazole hydrazones. Antimicrob. Agents Chemother. 2016, 60, 4217-4228. [CrossRef] [PubMed]

12. Yurttaş, L.; Özkay, Y.; Duran, M.; Turan-Zitouni, G.; Özdemir, A.; Canturk, Z.; Kücükoğlu, K.; Kaplancıklı, Z.A. Synthesis and antimicrobial activity evaluation of new dithiocarbamate derivatives bearing thiazole/benzothiazole rings. Phosphorus Sulfur Silicon Relat. Elem. 2016, 191, 1166-1173. [CrossRef]

13. Amnerkar, N.D.; Bhongade, B.A.; Bhusari, K.P. Synthesis and biological evaluation of some 4-(6-substituted-1,3-benzothiazol-2-yl)amino-1,3-thiazole-2-amines and their Schiff bases. Arab. J. Chem. 2015, 8, 545-552. [CrossRef]

14. Dar, A.A.; Shadab, M.; Khan, S.; Ali, N.; Khan, A.T. One-pot synthesis and evaluation of antileishmanial activities of functionalized S-alkyl/aryl benzothiazole-2-carbothioate scaffold. J. Org. Chem. 2016, 81, 3149-3160. [CrossRef] [PubMed]

15. Kharbanda, C.; Alam, M.S.; Hamid, H.; Javed, K.; Bano, S.; Dhulap, A.; Ali, Y.; Nazreen, S.; Haider, S. Synthesis and evaluation of pyrazolines bearing benzothiazole as anti-inflammatory agents. Bioorg. Med. Chem. 2014, 22, 5804-5812. [CrossRef] [PubMed] 
16. Moreno-Díaz, H.; Villalobos-Molina, R.; Ortiz-Andrade, R.; Díaz-Coutiño, D.; Medina-Franco, J.L.; Webster, S.P.; Binnie, M.; Estrada-Soto, S.; Ibarra-Barajas, M.; León-Rivera, I.; et al. Antidiabetic activity of N-(6-substituted-1,3-benzothiazol-2-yl)benzenesulfonamides. Bioorg. Med. Chem. Lett. 2008, 18, 2871-2877. [CrossRef] [PubMed]

17. Karali, N.; Güzel, O.; Ozsoy, N.; Ozbey, S.; Salman, A. Synthesis of new spiroindolinones incorporating a benzothiazole moiety as antioxidant agents. Eur. J. Med. Chem. 2010, 45, 1068-1077. [CrossRef] [PubMed]

18. Costanzo, M.J.; Yabut, S.C.; Almond, H.R., Jr.; Andrade-Gordon, P.; Corcoran, T.W.; De Garavilla, L.; Kauffman, J.A.; Abraham, W.M.; Recacha, R.; Chattopadhyay, D.; et al. Potent, small-molecule inhibitors of human mast cell tryptase. Antiasthmatic action of a dipeptide-based transition-state analogue containing a benzothiazole ketone. J. Med. Chem. 2003, 46, 3865-3876. [PubMed]

19. Khan, K.M.; Mesaik, M.A.; Abdalla, O.M.; Rahim, F.; Soomro, S.; Halim, S.A.; Mustafa, G.; Ambreen, N.; Khalid, A.S.; Taha, M.; et al. The immunomodulation potential of the synthetic derivatives of benzothiazoles: Implications in immune system disorders through in vitro and in silico studies. Bioorg. Chem. 2016, 64, 21-28. [CrossRef] [PubMed]

20. Hamdy, N.A.; Abdel-Aziz, H.A.; Kamel, G.M.; Fakhr, I.M. Convenient synthesis, anti-inflammatory, analgesic and ulcerogenic activites of some new bis-hydrazones and pyrazole derivatives. Acta Pol. Pharm. 2013, 70, 469-480. [PubMed]

21. Kaplancikli, Z.A.; Altintop, M.D.; Turan-Zitouni, G.; Ozdemir, A.; Can, O.D. Synthesis and analgesic activity of some acetamide derivatives. J. Enzym. Inhib. Med. Chem. 2012, 27, 275-280. [CrossRef] [PubMed]

22. Ali, R.; Siddiqui, N. New benzo[d]thiazol-2-yl-aminoacetamides as potential anticonvulsants: Synthesis, activity and prediction of molecular properties. Arch. Pharm. (Weinheim) 2015, 348, 254-265. [CrossRef] [PubMed]

23. Liu, D.C.; Zhang, H.J.; Jin, C.M.; Quan, Z.S. Synthesis and biological evaluation of novel benzothiazole derivatives as potential anticonvulsant agents. Molecules 2016, 21, 164. [CrossRef] [PubMed]

24. Keri, R.S.; Quintanova, C.; Marques, S.M.; Esteves, A.R.; Cardoso, S.M.; Santos, M.A. Design, synthesis and neuroprotective evaluation of novel tacrine-benzothiazole hybrids as multi-targeted compounds against Alzheimer's disease. Bioorg. Med. Chem. 2013, 21, 4559-4569. [CrossRef] [PubMed]

25. Özkay, U.D.; Can, O.D.; Özkay, Y.; Öztürk, Y. Effect of benzothiazole/piperazine derivatives on intracerebroventricular streptozotocin-induced cognitive deficits. Pharmacol. Rep. 2012, 64, 834-847. [CrossRef]

26. Mohsen, U.A.; Kaplancikli, Z.A.; Özkay, Y.; Yurttaş, L. Synthesis and evaluation of anti-acetylcholinesterase activity of some benzothiazole based new piperazine-dithiocarbamate derivatives. Drug Res. 2015, 65, 176-183. [CrossRef]

27. Demir Özkay, U.; Can, O.D.; Sağlık, B.N.; Çevik, U.A.; Levent, S.; Özkay, Y.; Ilgın, S.; Atlı, Ö. Design, synthesis, and AChE inhibitory activity of new benzothiazole-piperazines. Bioorg. Med. Chem. Lett. 2016, 26, 5387-5394. [CrossRef] [PubMed]

28. Kaya, B.; Sağlık, B.N.; Levent, S.; Özkay, Y.; Kaplancıklı, Z.A. Synthesis of some novel 2-substituted benzothiazole derivatives containing benzylamine moiety as monoamine oxidase inhibitory agents. J. Enzym. Inhib. Med. Chem. 2016, 31, 1654-1661. [CrossRef] [PubMed]

29. Firooznia, F.; Cheung, A.W.; Brinkman, J.; Grimsby, J.; Gubler, M.L.; Hamid, R.; Marcopulos, N.; Ramsey, G.; Tan, J.; Wen, Y.; et al. Discovery of benzothiazole-based adenosine A2B receptor antagonists with improved A2A selectivity. Bioorg. Med. Chem. Lett. 2011, 21, 1933-1936. [CrossRef] [PubMed]

30. Anzini, M.; Chelini, A.; Mancini, A.; Cappelli, A.; Frosini, M.; Ricci, L.; Valoti, M.; Magistretti, J.; Castelli, L.; Giordani, A.; et al. Synthesis and biological evaluation of amidine, guanidine, and thiourea derivatives of 2-amino(6-trifluoromethoxy)benzothiazole as neuroprotective agents potentially useful in brain diseases. J. Med. Chem. 2010, 53, 734-744. [CrossRef] [PubMed]

31. Carboni, S.; Hiver, A.; Szyndralewiez, C.; Gaillard, P.; Gotteland, J.P.; Vitte, P.A. AS601245 (1,3-benzothiazol-2 -yl(2-[[2-(3-pyridinyl)ethyl]amino]-4-pyrimidinyl)acetonitrile): A c-Jun NH2-terminal protein kinase inhibitor with neuroprotective properties. J. Pharmacol. Exp. Ther. 2004, 310, 25-32. [CrossRef] [PubMed]

32. Sharma, P.C.; Sinhmar, A.; Sharma, A.; Rajak, H.; Pathak, D.P. Medicinal significance of benzothiazole scaffold: An insight view. J. Enzym. Inhib. Med. Chem. 2013, 28, 240-266. [CrossRef] [PubMed] 
33. Wang, S.; Chen, Y.; Zhao, S.; Xu, X.; Liu, X.; Liu, B.F.; Zhang, G. Synthesis and biological evaluation of a series of benzoxazole/benzothiazole-containing 2,3-dihydrobenzo[ $b][1,4]$ dioxine derivatives as potential antidepressants. Bioorg. Med. Chem. Lett. 2014, 24, 1766-1770. [CrossRef] [PubMed]

34. Zhu, X.Y.; Etukala, J.R.; Eyunni, S.V.; Setola, V.; Roth, B.L.; Ablordeppey, S.Y. Benzothiazoles as probes for the 5HT1A receptor and the serotonin transporter (SERT): A search for new dual-acting agents as potential antidepressants. Eur. J. Med. Chem. 2012, 53, 124-132. [CrossRef] [PubMed]

35. Siddiqui, N.; Rana, A.; Khan, S.A.; Ahsan, W.; Alam, M.S.; Ahmed, S. Analgesic and antidepressant activities of benzothiazole-benzamides. Biomed. Pharmacol. J. 2008, 1, 297-300.

36. Oliveira, C.E.; Sari, M.H.; Zborowski, V.A.; Araujo, P.C.; Nogueira, C.W.; Zeni, G. p,p'-Methoxyl-diphenyl diselenide elicits an antidepressant-like effect in mice without discontinuation anxiety phenotype. Pharmacol. Biochem. Behav. 2017, 154, 31-38. [CrossRef] [PubMed]

37. Can, Ö.D.; Özkay, Ü.D.; Üçel, U.İ. Anti-depressant-like effect of vitexin in BALB/c mice and evidence for the involvement of monoaminergic mechanisms. Eur. J. Pharmacol. 2013, 699, 250-257. [CrossRef] [PubMed]

38. Cryan, J.F.; Mombereau, C.; Vassout, A. The tail suspension test for assessing antidepressant activity: Review of pharmacological and genetic studies in mice. Neurosci. Biobehav. Rev. 2005, 29, 571-625. [CrossRef] [PubMed]

39. Steru, L.; Chermat, R.; Thierry, B.; Simon, P. The tail suspension test: A new method for screening antidepressants in mice. Psychopharmacology (Berl.) 1985, 85, 367-370. [CrossRef] [PubMed]

40. Cryan, J.F.; Markou, A.; Lucki, I. Assessing antidepressant activity in rodents: Recent developments and future needs. Trends Pharmacol. Sci. 2002, 23, 238-245. [CrossRef]

41. Santiago, R.M.; Barbiero, J.; Martynhak, B.J.; Boschen, S.L.; da Silva, L.M.; Werner, M.F.; Da Cunha, C.; Andreatini, R.; Lima, M.M.; Vital, M.A. Antidepressant-like effect of celecoxib piroxicam in rat models of depression. J. Neural Transm. (Vienna) 2014, 121, 671-682. [CrossRef] [PubMed]

42. Brocardo, P.S.; Budni, J.; Kaster, M.P.; Santos, A.R.; Rodrigues, A.L. Folic acid administration produces an antidepressant-like effect in mice: Evidence for the involvement of the serotonergic and noradrenergic systems. Neuropharmacology 2008, 54, 464-473. [CrossRef] [PubMed]

43. Demir Özkay, Ü.; Yurttaş, L.; Özkay, Y.; Üçel, U.I.; Can, Ö.D.; Öztürk, Y. Synthesis of new 1-phenyl-2-(4substituted-piperazin-1-yl)-propanol derivatives and evaluation of their antidepressant-like effects. Arch. Pharm. Res. 2013, 36, 802-811. [CrossRef] [PubMed]

44. Van de Waterbeemd, H.; Gifford, E. ADMET in silico modelling: Towards prediction paradise? Nat. Rev. Drug Discov. 2003, 2, 192-204. [CrossRef] [PubMed]

45. QikProp, version 4.8; Schrödinger, LLC: New York, NY, USA, 2016.

46. Lipinski, C.A.; Lombardo, F.; Dominy, B.W.; Feeney, P.J. Experimental and computational approaches to estimate solubility and permeability in drug discovery and development settings. Adv. Drug Deliv. Rev. 2001, 46, 3-26. [CrossRef]

47. Jorgensen, W.L.; Duffy, E.M. Prediction of drug solubility from structure. Adv. Drug Deliv. Rev. 2002, 54, 355-366. [CrossRef]

48. Demir Özkay, Ü.; Özkay, Y.; Can, Ö.D. Synthesis and analgesic effects of 2-(2-carboxyphenylsulfanyl)$\mathrm{N}$-(4-substitutedphenyl)acetamide derivatives. Med. Chem. Res. 2011, 20, 152-157. [CrossRef]

49. Can, O.D.; Demir Özkay, Ü.; Kıyan, H.T.; Demirci, B. Psychopharmacological profile of Chamomile (Matricaria recutita L.) essential oil in mice. Phytomedicine 2012, 19, 306-310. [CrossRef] [PubMed]

50. Detke, M.J.; Lucki, I. Detection of serotonergic and noradrenergic antidepressants in the rat forced swimming test: The effects of water depth. Behav. Brain Res. 1996, 73, 43-46. [CrossRef]

51. Palotai, M.; Telegdy, G.; Tanaka, M.; Bagosi, Z.; Jászberényi, M. Neuropeptide AF induces anxiety-like and antidepressant-like behavior in mice. Behav. Brain Res. 2014, 274, 264-269. [CrossRef] [PubMed]

52. Can, O.D.; Ozkay, U.D. Effects of Hypericum montbretti extract on the central nervous system and involvement of GABA (A)/Benzodiazepine receptors in its pharmacological activity. Phytother. Res. 2012, 26, 1695-1700. [CrossRef] [PubMed]

53. Votava, M.; Hess, L.; Slíva, J.; Krsiak, M.; Agová, V. Dexmedetomidine selectively suppresses dominant behavior in aggressive and sociable mice. Eur. J. Pharmacol. 2005, 523, 79-85. [CrossRef] [PubMed]

Sample Availability: Samples of the compounds $3 \mathbf{a}-\mathbf{h}$ are available from the authors. 
(C) 2017 by the authors. Licensee MDPI, Basel, Switzerland. This article is an open access article distributed under the terms and conditions of the Creative Commons Attribution (CC BY) license (http:/ / creativecommons.org/licenses/by/4.0/). 